\title{
FDTD Analysis of the Current Distribution within the Grounding System for a Wind Turbine Generation Tower Struck by Lightning
}

\author{
Mitsuhiro Nagao Student Member (Doshisha University, dth0152@mail4.doshisha.ac.jp) \\ Naoto Nagaoka Member (Doshisha University, nnagaoka@mail.doshisha.ac.jp) \\ Yoshihiro Baba Member (Doshisha University, ybaba@mail.doshisha.ac.jp)
}

Akihiro Ametani Member (Doshisha University, aametani@mail.doshisha.ac.jp)

Keywords: wind turbine generation tower, lightning current, grounding, FDTD method

Transient current distribution within the grounding system for a wind-turbine-generation tower of height $61 \mathrm{~m}$ struck by lightning, which is shown in Fig. 1, has been calculated using the finitedifference time-domain (FDTD) method. The grounding grid of the lightning-struck tower is connected electrically via an insulated wire to one neighboring-tower grounding grid located $50 \mathrm{~m}$ away from it.

It has become clear that high-frequency components of a lightning current tend to flow in ground through the grounding grid of the lightning-struck tower, and they become larger with increasing the ground conductivity. Relatively-lower-frequency components of the lightning current flow in ground through each of the two grounding grids, roughly in inverse proportion to the grounding resistance of each grid. For example, when two identical grounding grids of the lightning-struck tower and the neighboring tower are buried in the same ground, about $50 \%$ of the lightning current flows in the grounding grid of the neighboring tower via the insulated wire connecting these two grounding grids (see Fig. 2). The magnitude of current flowing in the down conductor inside the tower is smaller than $4 \%$ of the tower base current in all cases considered in this paper (see Fig. 3).

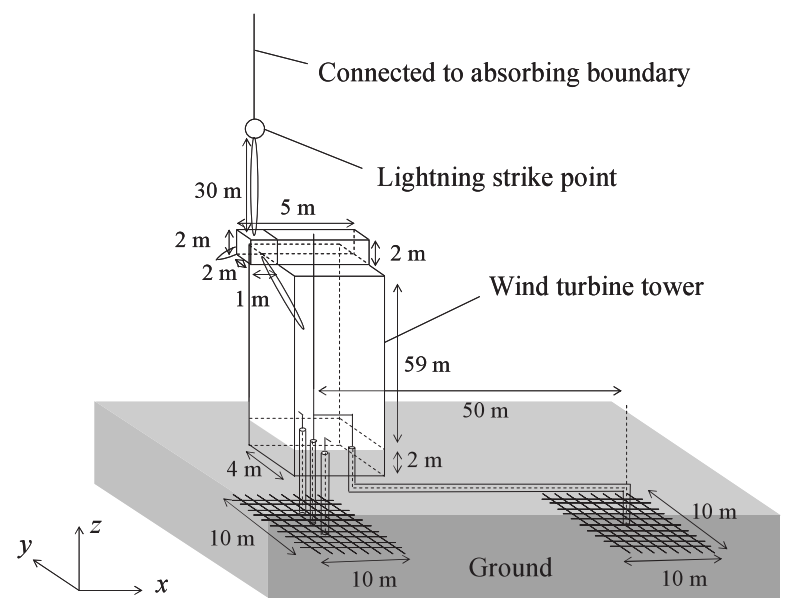

Fig. 1. A model of a 61-m-high wind-turbine-generation tower struck by lightning, to be analyzed using the FDTD method

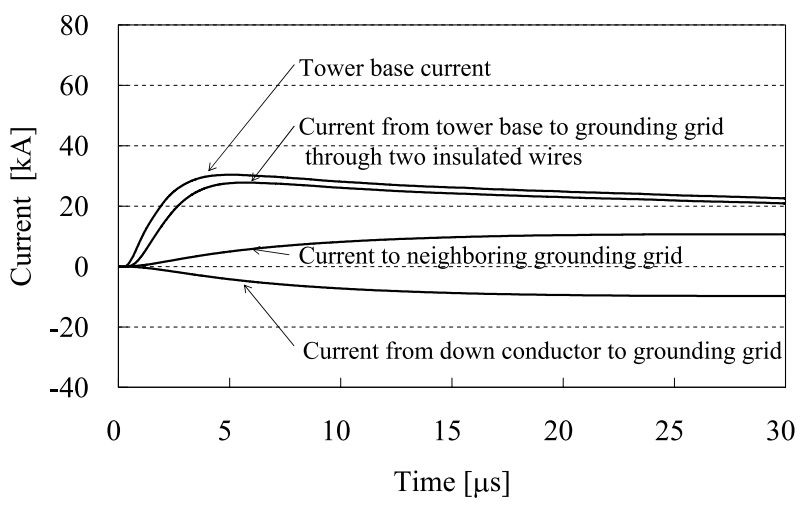

Fig. 2. Waveforms of current at the tower base, current flowing from the tower base to the grounding grid through two insulated grounding wires, current flowing from the down conductor inside the tower to the grounding grid through an insulated grounding wire, and current flowing out from the tower to the grounding grid of the neighboring tower in the case that the ground conductivity is $10 \mathrm{mS} / \mathrm{m}$

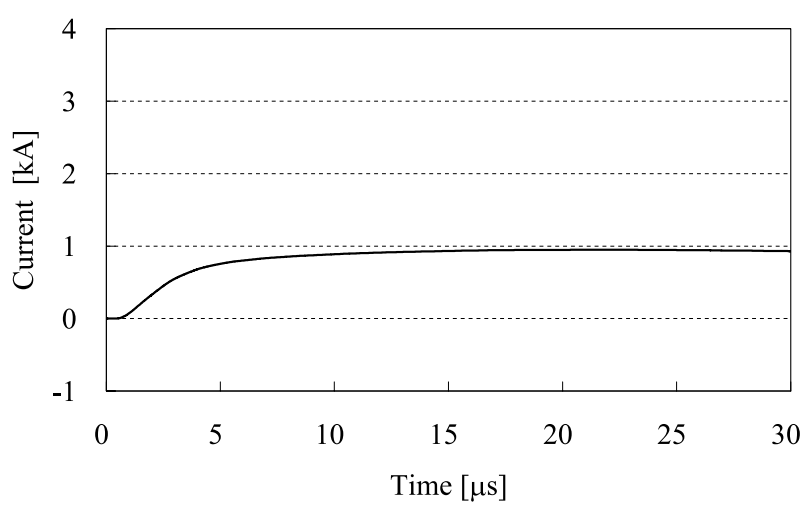

Fig. 3. Waveform of current observed at a height of $30 \mathrm{~m}$ along the down conductor inside the tower 


\title{
FDTD 法を用いた風力発電タワー雷撃時の電流分布解析
}

\author{
学生員 長尾 光紘* 正 員 長岡 直人* \\ 正 員 馬場 吉弘* 正員 雨谷 昭弘*
}

\author{
FDTD Analysis of the Current Distribution within the Grounding System \\ for a Wind Turbine Generation Tower Struck by Lightning
}

Mitsuhiro Nagao*, Student Member, Naoto Nagaoka*, Member, Yoshihiro Baba*, Member, Akihiro Ametani*, Member

Transient current distribution within the grounding system for a wind-turbine-generation tower of height $61 \mathrm{~m}$ struck by lightning has been calculated using the finite-difference time-domain (FDTD) method. The grounding grid for the lightning-struck tower considered in this paper is connected electrically via an insulated wire to one neighboring-tower grounding grid located $50 \mathrm{~m}$ away from it. High-frequency components of a lightning current tend to flow in ground through the grounding grid of the lightning-struck tower, and they become larger with increasing the ground conductivity. Relatively-lower-frequency components of the lightning current flow in ground through each of the two grounding grids roughly in inverse proportion to the grounding resistance of each grid. For example, when two identical grounding grids for the lightning-struck tower and the neighboring tower are buried in the same ground, about $50 \%$ of the lightning current flows in the grounding grid for the neighboring tower via the insulated wire connecting these two grounding grids. When the grounding resistance of the neighboring tower is about $1 / 4$ of that for the lightning-struck tower, about $4 / 5$ of the lightning current flows in the neighboring-tower grounding grid. This agrees well with the trend shown by Nagaoka et al. from their measurement in the grounding system for an actual wind-turbine-generation tower struck by natural lightning.

キーワード : 風力発電タワー, 雷電流, 接地, FDTD 法

Keywords: wind turbine generation tower, lightning current, grounding, FDTD method

\section{1. 緒言}

自然エネルギー有効利用の観点から, 近年, 風力発電所 が数多く建設されている。しかし, 頻繁に被雷する(1) こと から, 適切な雷害対策が風力発電所の運用効率の向上に不 可欠である。

風力発電設備での雷過電圧発生メカニズムを明らかにす る目的で, 山本ら (2)(3) は風力発電タワー各部に生じる雷過電 圧の縮小モデル実験を, 安田ら ${ }^{(4)(5)}$ は風力発電ファームの 雷過電圧の回路解析および風力発電夕ワーの接地電極サー ジ特性の FDTD（Finite-Difference Time-Domain）法 ${ }^{(6)}$ 用いた解析を行っており, 風力発電設備の各部で生じうる 雷過電圧の特徵が明らかにされつつある。最近, 長岡ら (7) は風力発電ファーム内の一風力発電タワーが実雷撃を受け た場合における同タワーの接地系各部に流れる雷電流を実

\footnotetext{
$*$ 同志社大学

干 610-0311 京田辺市多々羅都谷 1-3

Doshisha University

1-3, Miyakodani, Tatara, Kyotanabe 610-0311
}

測し，かなりの割合の雷電流がタワー脚部から連接接地線 に流出しているという測定結果を報告している。なお, 需 要家設備の接地グリッドから配電線への雷電流の流出（逆 流）現象やそれに起因した事故については, 比較的古くか ら横山ら ${ }^{(8)}$ によって指摘されており解明が進んでいる。

本論文では, FDTD 法を用いて, 風力発電夕ワーが被雷 した際のタワーおよび接地系（タワー脚部と接地グリッド との接続線, タワー内電気設備の接地線と接地グリッドと の接続線, 連接接地線等) の過渡電流分布を解析し, それ らに与える雷電流波形, 大地導電率および被雷タワーと隣 接タワーの接地抵抗の相違等の影響について検討を行った ので報告する。

\section{2. 計算モデル}

困 1(a)に計算モデルの全体図を, 同図 (b)に雷撃を受け たタワー脚部の詳細図を示す。このモデルは, タワー, ナ セル, ブレード 3 翼, 鉄筋コンクリート基礎（ただし，見 難くなることを避けるため, 図 1(a) の全体図には鉄筋コン クリート基礎を描いていない), 不完全導体大地に埋設され 


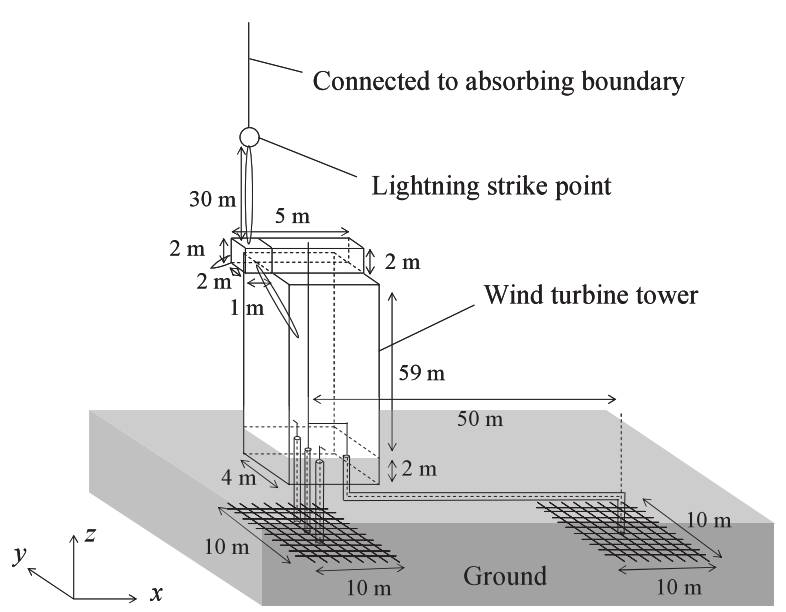

(a) Whole view

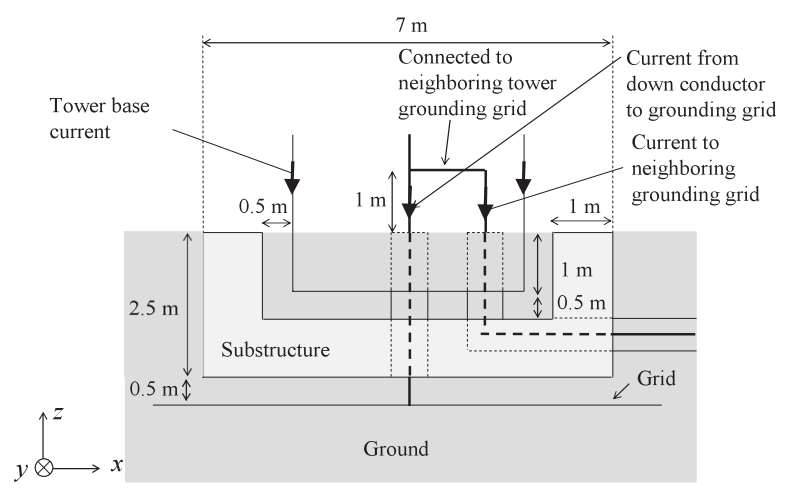

(b) $z-x$ side view of the tower footing, substructure, and grounding grid

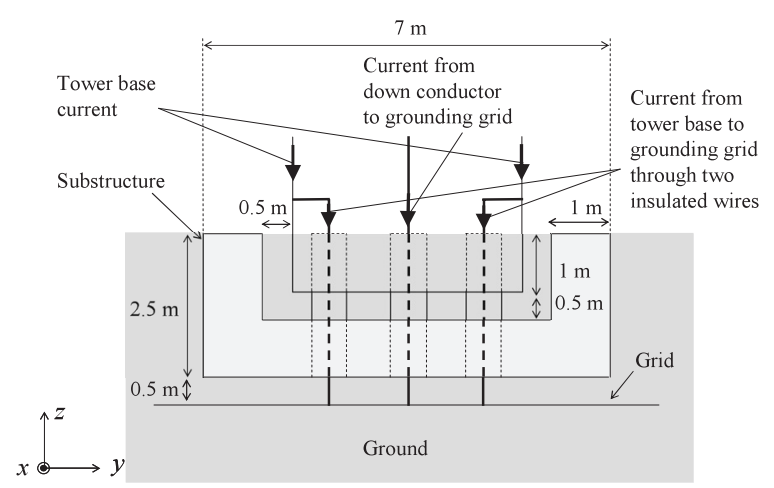

(c) $y-z$ side view of the tower footing, substructure, and grounding grid

図 1 被雷した風力発電タワーの FDTD 計算モデル

Fig. 1. A model of a 61-m-high wind-turbine-generation tower struck by lightning, to be analyzed using the FDTD method.

たタワーの接地グリッド，そこから $50 \mathrm{~m}$ 離れた隣接タワー の接地グリッド（ただし，隣接タワー地上部は接地系電流 分布にほとんど影響を与えないと考えられるため考慮して いない)，垂直な雷放電路抢よび雷電流を出力する電圧源か ら構成される。

解析空間は $75 \mathrm{~m} \times 75 \mathrm{~m} \times 150 \mathrm{~m}$ とし，これを一辺 $0.5 \mathrm{~m}$ の立方体セルで分割した。この解析空間を囲む 6 面には Liaoの二次吸収境界条件 ${ }^{(9)}$ を適用した。計算時間刻みは, Courantの安定条件を満たす $0.9430 \mathrm{~ns}$ と設定した。
風力発電タワーは地上高 $61 \mathrm{~m}$ とし, 脚部 1 メートルを埋 設した。地面下 $1 \mathrm{~m}$ から地上高 $59 \mathrm{~m}$ までは一辺 $4 \mathrm{~m}$ の正 方形断面を有する直方体で，そこから $61 \mathrm{~m}$ までは $2 \mathrm{~m} \times 5 \mathrm{~m}$ の長方形断面を有する直方体で（ナセル部分を）模擬した。 タワーおよびナセルは，ステンレス鋼であることを想定し， それらの導電率を $1.1 \times 10^{6} \mathrm{~S} / \mathrm{m}$ に設定した。また，タワー およびナセル内部は空洞とした。なお，これらを完全導体 と設定した場合の計算も行ったが，計算結果にほとんど相 違は見られなかった。

大地の導電率は $10 \mathrm{mS} / \mathrm{m}$, 比誘電率は 10 , 比透磁率は 1 , 大地の厚みは $30 \mathrm{~m}$ とした（下面は吸収境界面と設定）。こ の厚みは，この大地への周波数 $1 \mathrm{MHz}$ に抢ける電磁波の透 過深度 $3.6 \mathrm{~m}\left[=\left(2 \pi f \sigma \mu_{0}\right)^{-1 / 2}\right]$ に比べて充分大きい。

鉄筋コンクリート基礎は, 内側面積 $5 \mathrm{~m} \times 5 \mathrm{~m}$, 深さ $1.5 \mathrm{~m}$ の妌状の導体で模擬した。導電率は $9.9 \times 10^{6} \mathrm{~S} / \mathrm{m}$ （鉄の導 電率）と設定した。なお，細い鉄線を格子状に編んで作成し た $0.5 \mathrm{~m} \times 0.5 \mathrm{~m} \times 3 \mathrm{~m}$ の直方体接地電極の過渡応答特性実 測波形と，その電極を同じ大きさの金属塊で模擬して行っ

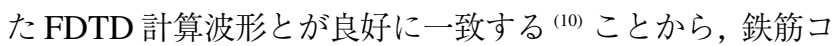
ンクリート基礎をこのように模擬することも妥当であると 考えられる。この鉄筋コンクリート基礎とタワー脚部との 間には $0.5 \mathrm{~m}$ のギャップを設け, その部分の導電率は大地 のそれと同じ $10 \mathrm{mS} / \mathrm{m}$ と設定した。このように基礎を設定 した理由は，タワーと鉄筋コンクリート基礎内の鉄筋が電 気的に完全に接続されているとは限らないと考えたためで ある。また，タワー脚部と基礎の間に設けた $0.5 \mathrm{~m}$ という 間隔は大きいが，これは本計算で使用したセルサイズ (一 辺 $0.5 \mathrm{~m}$ の立方体）に起因している。それらが電気的に良 好な接続を保っている場合の計算結果は，第〈4・4〉節で示 す。なお，実際のタワーでは，鉄筋コンクリート基礎の下 に複数の杭（鉄筋コンクリート製）が存在するが，本計算 では，それらは考慮しなかった。

接地グリッドは, 地表面から $3 \mathrm{~m}$ 下（鉄筋コンクリート 基礎下面から $0.5 \mathrm{~m}$ 下）に配置した。このグリッドの輪郭 は $10 \mathrm{~m} \times 10 \mathrm{~m}$ とし，網目の大きさは $1 \mathrm{~m} \times 1 \mathrm{~m}$ とした。 接地グリッドを構成する導体の等価半径は, 文献(11)より $0.115 \mathrm{~m}(=0.23 \times 0.5 \mathrm{~m})$ になる。この導体半径は一般的な 接地線導体の半径の 10 倍以上の大きさであるが，グリッ ド電極の接地抵抗地は主としてグリッド全体（輪郭）の大 きさで決まるため ${ }^{(12)}$ ，この導体半径の影響は小さいと考え られる。

この接地グリッドとタワー脚部は, 比誘電率 1 , 断面 $1 \mathrm{~m} \times 1 \mathrm{~m}$ の絶縁体の中心に配置した等価半径 $0.115 \mathrm{~m}$ (= $0.23 \times 0.5 \mathrm{~m})^{(13)}$ の導体 2 本で接続した。またタワー内電気 設備の接地線を模擬する引き下げ線の上端はタワー頂部に 接続し, 下端は 1 本の絶縁導体（断面 $1 \mathrm{~m} \times 1 \mathrm{~m}$ の絶縁体 の中心に配置した等価半径 $0.115 \mathrm{~m}$ の導体）を介して接地 グリッドに接続した。これらの絶縁導体を高導電率の土中 に埋設した場合，その特性インピーダンスは $90 \Omega$ 程度と なり，実際に用いられている被覆厚の小さい導体を埋設し 
た場合の特性インピーダンスの数倍の高さとなる。しかし， 長さが $4 \mathrm{~m}$ 程度と短いため, 立ち上がり時間数 $\mu \mathrm{s}$ の雷電流 を対象とする場合には，この相違の影響は顕著には生じな いと考えられる。

引き下げ線は，さらに $50 \mathrm{~m}$ 離れたところに設けた隣接夕 ワーの接地グリッドと絶縁導体で接続した。実際のタワー 間隔は，この数倍以上であることが多いが，FDTD 計算に おいてその間隔を忠実に模擬すると，それだけ解析空間と 計算時間が増大するため，この間隔とした。

なお, 上述したのと同じ理由で, 鉄筋コンクリート基礎と接 地グリッドは接続しておらず，その間には導電率 $10 \mathrm{mS} / \mathrm{m}$, 長さ $0.5 \mathrm{~m}$ のギャップが存在する。鉄筋コンクリート基礎 とタワー脚部，接地グリッドとの間を導線で接続した場合 の計算結果については第 $\langle 4 \cdot 4\rangle$ 節で示す。

ブレードは長さ $30 \mathrm{~m}$ の 3 翼で模擬し，ナセル中央部を中 心として各翼を $120^{\circ}$ 間隔で配置した。ブレードは，その材 質がガラスであることを想定し，導電率を $1.0 \times 10^{-14} \mathrm{~S} / \mathrm{m}$, 比誘電率を 4.2 に設定した。ただし，各ブレード表面の先 端からナセルまでの間に等価半径 $0.115 \mathrm{~m}$ の導体を設けた。 この導体半径は, 一般的なブレード内部の引き下げ線の半 径に比べて大きいが，ブレード上のサージ伝搬時間 $(0.1 \mu \mathrm{s}$ 程度）より充分長い立ち上がり時間を有する雷電流を対象 とする場合には，この相違の計算結果に与える影響は小さ いと考えられる。ブレード上のサージ伝搬時間に近い立ち 上がり時間を有する雷電流を対象とする場合には，タワー に流入する初期のピーク值が影響を受けると考えられる。

雷撃点は，ブレードの一翼（垂直に配置した翼）の先端 とし，その点と雷放電路を模擬する垂直導体との間に電圧 源と $500 \Omega$ の直列抵抗を挿入した。なお， $500 \Omega$ の直列抵 抗を挿入したのは，夕ワーから見た模擬雷放電路の等価イ ンピーダンスを実際の值 $(600 \sim 2500 \Omega)^{(14)}$ に近づけるた めである。電圧源は，ピーク值 $30 \mathrm{kA}$ ，立ち上がり時間約 $2.5 \mu \mathrm{s}$ （10-90\%立ち上がり時間）, 波尾長約 $70 \mu \mathrm{s}$ の電流波 を出力するように設定した。また，雷放電路を模擬する垂 直導体の上端は吸収境界面に接続した。

\section{3. 計算結果}

大地導電率が $10 \mathrm{mS} / \mathrm{m}$ ，鉄筋コンクリート基礎とタワー 脚部，接地グリッドとの間を導線で接続していない場合の 電圧源（雷放電路と垂直ブレード先端の間）から流入され る電流波形を図 2 に示す。図 3 には，タワー脚部（地表面 から $0.75 \mathrm{~m}$ 上）の電流波形, タワー脚部から接地グリッド に流入する電流波形（タワー脚部と接地グリッドをつなぐ

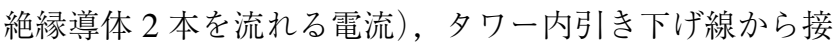
地グリッドに流入する電流波形（観測点は連接接地線との 接続点より下側）および連接接地線への流出電流波形を示 す。図 4 には，タワー中央の引き下げ線に流れる電流波形 （地表面から $30 \mathrm{~m}$ 上側で観測）を示す。ただし，連接接地 線電流以外は，下向きの正極性電流を正として表示してい る。連接接地線電流は, 雷撃夕ワーから流出する正極性の

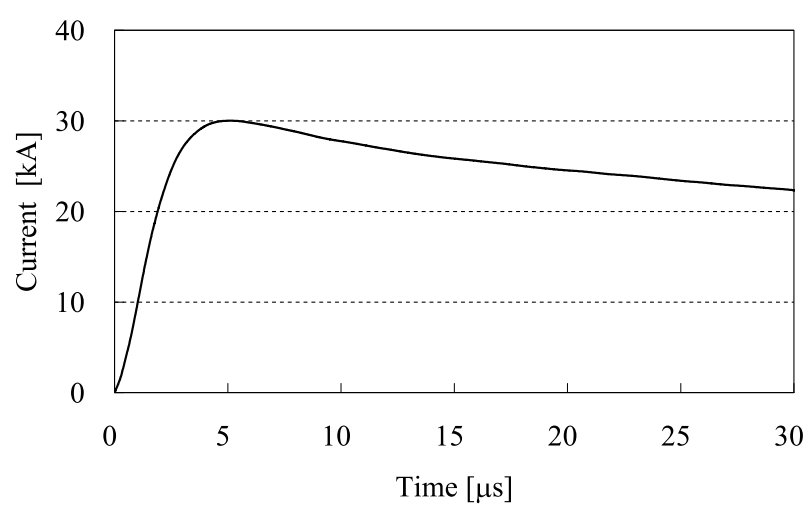

図 2 電圧源から流入される電流波形

Fig. 2. Waveform of current injected by the voltage source.

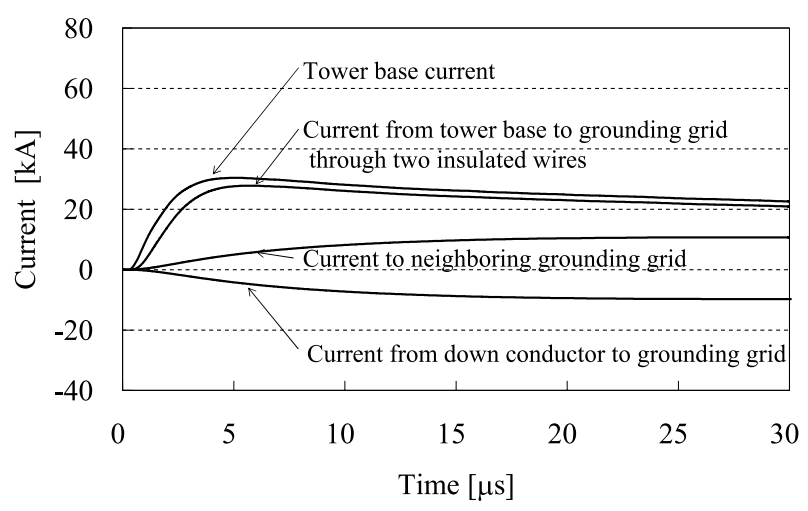

図 3 タワー脚部電流，タワー脚部から絶縁導体 を介して接地グリッドに流入する電流，タワー内 引き下げ線から接地グリッドに流入する電流およ び連接接地線への流出電流の各波形（下向きに 流れる電流を正として表示。連接接地線電流は 流出電流を正として表示)

Fig. 3. Waveforms of current at the tower base, current flowing from the tower base to the grounding grid through two insulated grounding wires, current flowing from the down conductor inside the tower to the grounding grid through an insulated grounding wire, and current flowing out from the tower to the grounding grid of a neighboring tower.

電流を正として表示している。

図 3 に示したタワー脚部電流と図 4 に示したタワー中央 の引き下げ線に流れる電流を比較すると, タワー脚部電流 のピーク值が $30 \mathrm{kA}$ であるのに対しタワー中央の引き下げ 線に流れる電流のピーク值は約 $1 \mathrm{kA}$ と大幅に小さくなっ ている(夕ワー脚部電流の約 $3 \%$ )。なお, タワー中央部の 引き下げ線に流れるこの電流の立ち上がり時刻は, 夕ワー 脚部電流の立ち上がり時刻より遅れていることから，初期 の引き下げ線電流は雷撃点から直接流入したものではなく, タワー脚部から流入した電流であると考えられる。以下で は，この引き下げ線電流について考察する。図 3 より，夕 
ワー脚部電流のほとんど (約 90\%) は，2 本の絶縁導体を介 して接地グリッドに流入している。このうちの何割か（図 3 参照：5 $\mathrm{s}$ 時点で約 20\%）は，中央の絶縁導体を介して連接 接地線に流出している。このため, タワー内部の地表面付 近においては，中心方向の電界が発生する。この電界は，中 央の引き下げ線を上向きに伝搬する同軸モードの負極性電 流を駆動する。上向きに伝搬する負極性電流波は，下向き に伝搬する正極性電流波と等価であるため，図 4 において その極性は正として表示されている。なお，準定常状態に おいて引き下げ線に流入している下向きの正極性電流（約 $1 \mathrm{kA})$ は，頂部から流入したものと考えてよい。

接地グリッドと連接接地線およびタワー内引き下げ線を つなぐ絶縁導体に流れる電流は, 図 3 において負となって いる。これは, 一度接地グリッドに流入した雷電流が引き下 げ線を介して連接接地線に流出していることを示している。 タワー脚部電流に対する連接接地線への電流流出率は, $5 \mu \mathrm{s}$ 時点において約 15\%，30 $\mu \mathrm{s}$ 時点において約 50\%となって いる。なお，本論文の FDTD 計算モデルでは隣接タワーの 接地グリッドを $50 \mathrm{~m}$ 離れたところに設けたが，実際の夕 ワー間隔はこの数倍以上である。隣接タワーの接地グリッ ドをこのように近接して設置したことにより，連接接地線 への電流流出率が準定常值 $(50 \%)$ に至る時間が実際より 短くなっていると考えられる。

連接接地線が存在しない場合には，接地グリッドに流入 した電流はそこから大地に流入する(図は省略)。タワー脚 部から 2 本の絶縁導体を介して接地グリッドに流入する電 流の流出率（タワー脚部電流に対する）は，タワー脚部電 流に対して $5 \mu \mathrm{s}$ 時点および $30 \mu \mathrm{s}$ 時点において約 $90 \%$ あ り, 連接接地線が存在する場合とほぼ同じである。タワー 内の引き下げ線に流れる電流のピーク值は, タワー脚部電

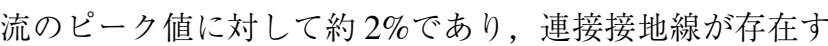
る場合より若干小さくなる。

次節では, 連接接地線への雷電流の流出率に与える雷電 流波形, 大地導電率, 雷撃タワーと隣接タワーの接地抵抗

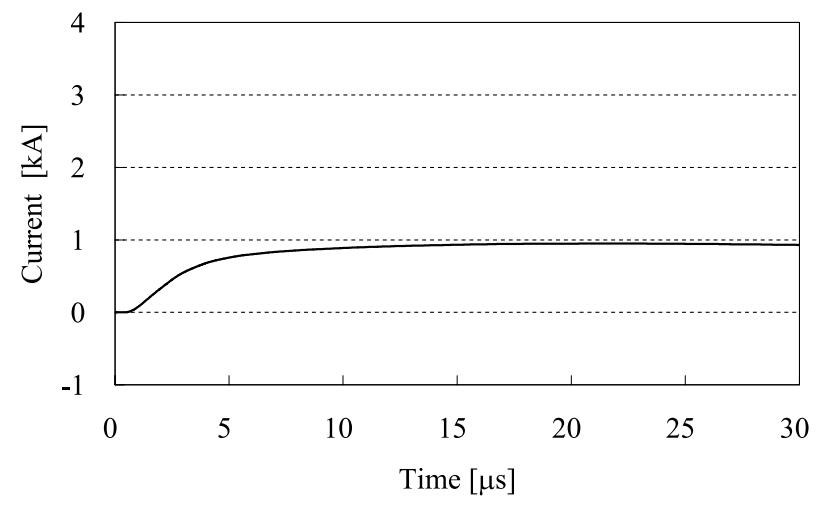

図 4 タワー中央の引き下げ線に流れる電流波形 (地表面より $30 \mathrm{~m}$ 上側で観測)

Fig. 4. Waveform of current observed at a height of $30 \mathrm{~m}$ along the down conductor inside the tower.
の相違，および鉄筋コンクリート基礎とタワー脚部，接地 グリッドとの間の接続の有無の影響について検討を行う。

\section{4. 検 討}

〈4・1〉雷電流波形の影響＼cjkstart前節では，立ち上がり時 間 $2.5 \mu \mathrm{s}$ （10-90\%立ち上がり時間）の雷電流が流入した場 合の計算を行った。本節では，後続雷撃を想定し，立ち上 がり時間が $0.15 \mu \mathrm{s}$ の雷電流が流入した場合における接地 系の各部の雷電流分布の計算を行う。大地導電率は前節の 計算と同じ $10 \mathrm{mS} / \mathrm{m}$ とする。

図 5 に電圧源から流入される電流波形 (ピーク值 $30 \mathrm{kA}$ ) を示す。この波形には 2 つのピークが観測されるが，一番 目のピークは電圧源より $30 \mathrm{~m}$ 下のブレード下端とタワー 頂部の接続点からの反射波に起因したものであり，二番目 のピークは電圧源から約 $90 \mathrm{~m}$ 下に位置する大地面からの 反射波に起因したものである。

図 6 に, タワー脚部の電流波形, タワー脚部から接地グ リッドに流入する電流波形, タワー内引き下げ線から接地 グリッドに流入する電流波形および連接接地線への流出電 流波形を示す。図 6 には, タワー中央の引き下げ線に流れ る電流波形を示す。

図 6 に示したタワー脚部電流と図 7 に示したタワー中央 の引き下げ線に流れる電流を比較すると, 夕ワー脚部電流 のピーク值が $47 \mathrm{kA}$ であるのに対しタワー中央の引き下げ 線に流れる電流のピーク值は $0.7 \mathrm{kA}$ と大幅に小さくなって

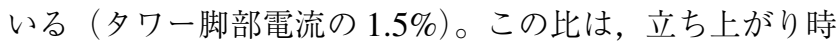
間が $2.5 \mu \mathrm{s}$ の場合のそれ $(3 \%)$ より低い。

また，雷電流の立ち上がり時間 $0.15 \mu \mathrm{s}$ の場合において は, 初期 $(1 \mu \mathrm{s}$ 程度) に, $50 \%$ 以上の電流がタワー脚部から 大地に直接流出している。しかし，それ以降は，雷電流の 立ち上がり時間が $2.5 \mu \mathrm{s}$ の場合と同様に，タワー脚部の電 流のほとんどが 2 本の絶縁導体を介して接地グリッドに流 入している。接地グリッドに流入した雷電流の一部は大地 に流出し, 残りはタワー内部の引き下げ線と接地グリッド をつなぐ絶導導体を介して連接接地線に流出している。夕

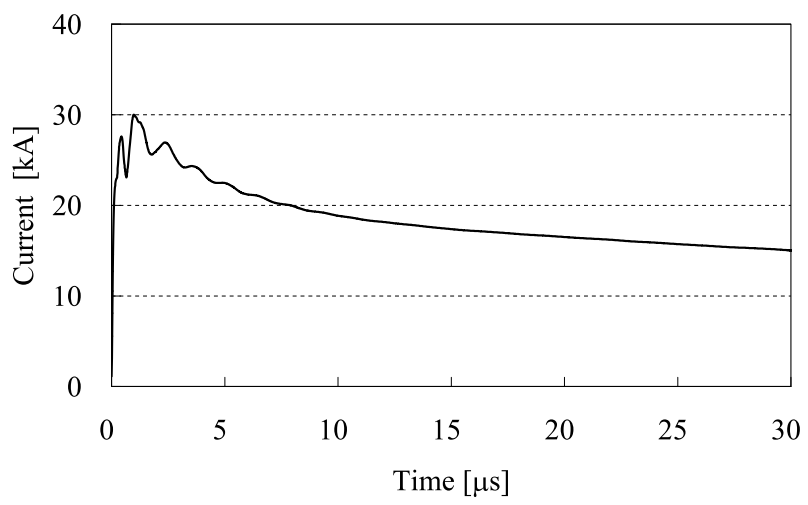

図 5 電圧源から流入される電流波形

Fig. 5. Waveform of current injected by the voltage source. 


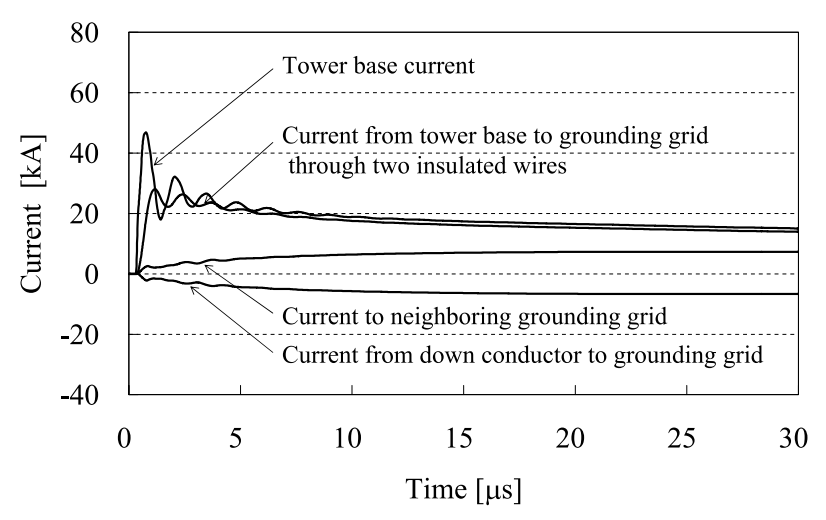

図 6 雷電流の立ち上がり時間が $0.15 \mu \mathrm{s}$ の場合 における雷撃を受けたタワーの接地系各部の 電流波形

Fig. 6. Waveforms of currents at different points within the grounding system for the lightning-struck tower when the $10-$ to- $90 \%$ risetime of injected lightning current is $0.15 \mu \mathrm{s}$.

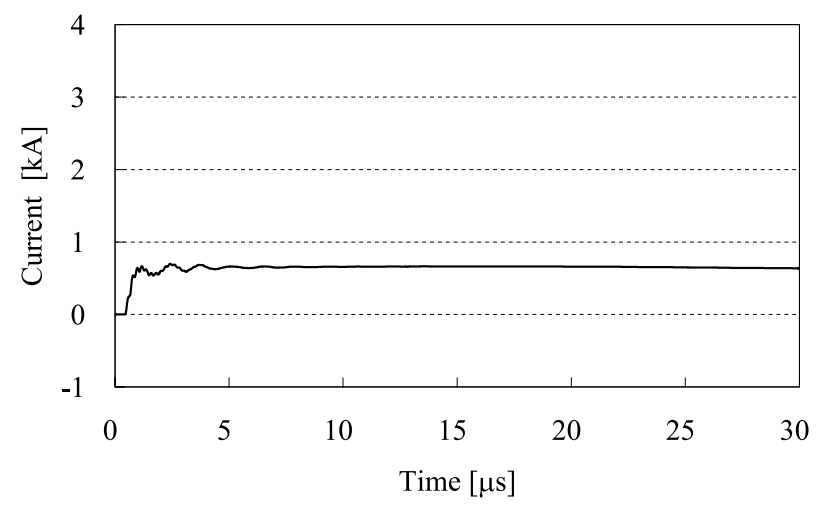

図 7 雷電流の立ち上がり時間が $0.15 \mu \mathrm{s}$ の場合に おけるタワー中央の引き下げ線に流れる電流波形 Fig. 7. Waveform of current observed at a height of $30 \mathrm{~m}$ along the down conductor inside the tower when the 10-to-90\% risetime of injected lightning current is $0.15 \mu \mathrm{s}$.

ワー脚部電流に対する連接接地線への電流流出率は, $5 \mu \mathrm{s}$ 時点で 10\%, $30 \mu \mathrm{s}$ 時点で 50\%となっている。このように, 準定常状態に扔いて約半分の雷電流が連接接地線に流出す るのは, 雷撃を受けたタワーの接地グリッドとそれと全く 同一の隣接タワーの接地グリッドが同じ導電率を有する大 地内に並列に存在するため, 言い換えれば，それらの接地 抵抗值が全く同一であるためである。

以上のことから, 雷電流の急峻成分は雷撃を受けた夕ワー の接地グリッドを介して大地に流出する割合が高いが，緩 やかな成分は各接地グリッドの接地抵抗の逆比割合で分流 することが確認された。連接数が増し，連接接地の合成抵 抗值が低下すれば，雷撃を受けたタワーから連接接地線へ の流出率はさらに高くなることが予想される。

$\langle\mathbf{4} \cdot \mathbf{2}\rangle$ 大地導電率の影響 前節までは, 大地導電率

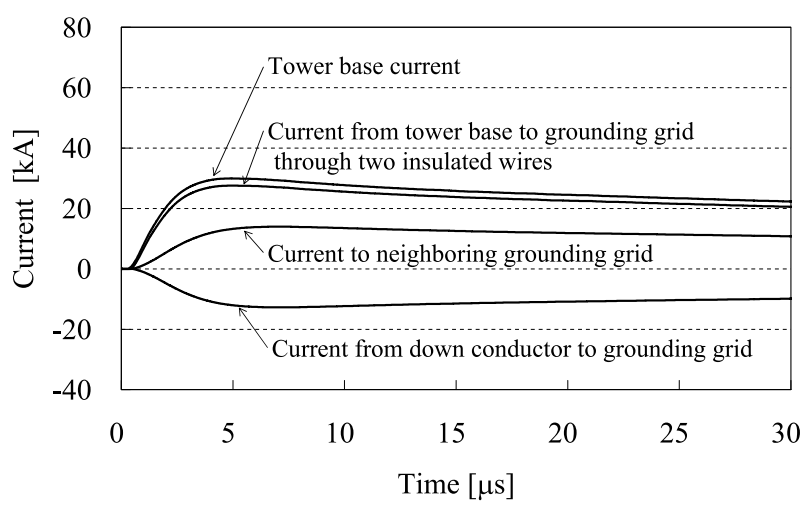

図 8 大地導電率が $1 \mathrm{mS} / \mathrm{m}$ の場合に扔ける雷撃 を受けたタワーの接地系各部の電波形

Fig. 8. Waveforms of currents at different points within the grounding system for the lightning-struck tower when the ground conductivity is $1 \mathrm{mS} / \mathrm{m}$.

を $10 \mathrm{mS} / \mathrm{m}$ と設定して計算を行ってきた。本節では, 大地 導電率を $1 \mathrm{mS} / \mathrm{m}$ に変更した場合に扔ける風力発電タワー 接地系各部の雷電流分布の計算を行う。なお，この計算で は雷電流の立ち上がり時間は約 $2.5 \mu \mathrm{s}$ とする。

この条件で計算したタワー脚部の電流波形, タワー脚部 から接地グリッドに流入する電流波形, タワー内引き下げ 線から接地グリッドに流入する電流波形掞よび連接接地線 への流出電流波形を図 8 に示す。

図 8 より, 大地導電率が $1 \mathrm{mS} / \mathrm{m}$ の場合にも, タワー脚部 電流のほとんど $(5 \mu \mathrm{s}$ 時点抢よび $30 \mu \mathrm{s}$ 時点で約 $90 \%)$ の 電流は, 2 本の絶縁導体を介して接地グリッドに流入してい る。また接地グリッドに流入した雷電流の約半分が連接接 地線に流出している。タワー脚部電流に対する連接接地線 への電流流出率は, $5 \mu \mathrm{s}$ 時点で $45 \%, 30 \mu \mathrm{s}$ 時点で $50 \%$ と なっている。大地導電率が $10 \mathrm{mS} / \mathrm{m}$ の場合に比べて, $5 \mu \mathrm{s}$ での流出率は高くなっているが $(20 \rightarrow 45 \%), 30 \mu \mathrm{s}$ での 流出率はほぼ⿵冂⿱一口冋乚である。タワー中央の引き下げ線に流れ る電流は示していないが，波形は図 4 とほぼ同じである。 引き下げ線電流のピーク值はタワー脚部電流ピーク值の約 $4 \%$ となって㧍り, 大地導電率が $10 \mathrm{mS} / \mathrm{m}$ の場合（約 3\%) に比べて若干大きくなっている。

以上のことから, 雷電流の急峻成分に対しては, 大地導 電率が低いほど連接接地線への流出率が高くなること, 緩 やかな成分に対しては, 各接地グリッドの抵抗值の逆比で 各接地グリッドに分流することが確認された。

〈4・3〉隣接タワーの接地抵抗の影響＼cjkstart前節までは, 雷 撃を受けたタワーの接地グリッドの形状と隣接タワーの接 地グリッドの形状を同一として計算を行ってきた。本節で は, 雷撃を受けたタワーの接地グリッド形状をそのままとし (輪郭 $10 \mathrm{~m} \times 10 \mathrm{~m}$, グリッドの網目の大きさ $1 \mathrm{~m} \times 1 \mathrm{~m}$, 埋設 深さ $3 \mathrm{~m})$, 隣接タワーの接地電極を平面グリッドから直方 体グリッド $(10 \mathrm{~m} \times 10 \mathrm{~m} \times 20 \mathrm{~m}$, グリッドの網目の大きさ は $1 \mathrm{~m} \times 1 \mathrm{~m} \times 1 \mathrm{~m}$, 埋設深さ $3 \sim 23 \mathrm{~m})$ に変更して計算を行 


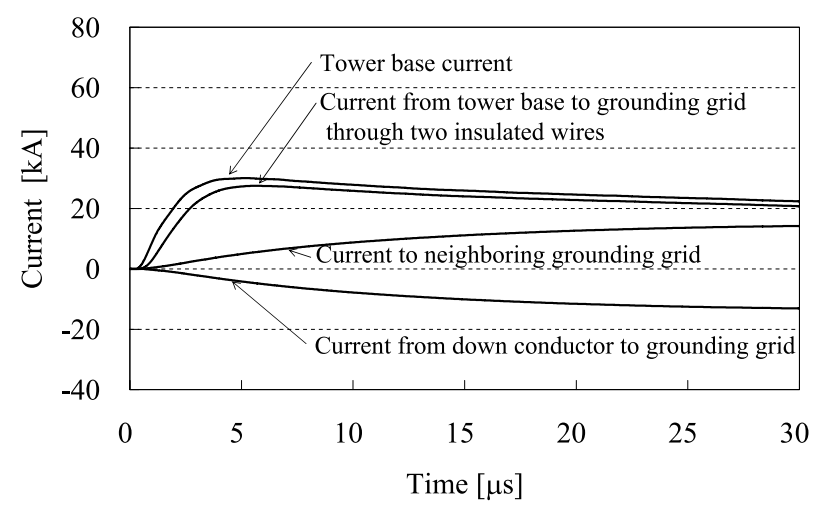

図 9 雷撃を受けたタワーの接地グリッドの 接地抵抗が隣接タワーのそれより約 4 倍高い 場合における雷撃を受けたタワーの接地系 各部の電波形

Fig. 9. Waveforms of currents at different points within the grounding system for the lightning-struck tower when the ground resistance of the lightning-struck tower is about 4 times higher than that of the neighboring tower.

う。なお，各接地グリッドを対象に大地導電率を $10 \mathrm{mS} / \mathrm{m}$ と設定して別途行った計算によれば, $10 \mathrm{~m} \times 10 \mathrm{~m}$ の平面接 地グリッドの接地抵抗值は約 $2 \Omega, 10 \mathrm{~m} \times 10 \mathrm{~m} \times 20 \mathrm{~m}$ の 直方体接地グリッドのそれは約 $0.5 \Omega$ であった。

上述の条件で計算したタワー脚部の電流波形，タワー脚 部から接地グリッドに流入する電流波形, タワー内引き下 げ線から接地グリッドに流入する電流波形および連接接地 線への流出電流波形を図 9 に示す。ただし，大地導電率は $10 \mathrm{mS} / \mathrm{m}$ ，雷電流の立ち上がり時間は約 $2.5 \mu \mathrm{s}$ とした。

タワー脚部電流のほとんど $(5 \mu \mathrm{s}$ 時点および $30 \mu \mathrm{s}$ 時点で 約 90\%）は，2 本の絶縁導体を介して接地グリッドに流入 している。接地グリッドに流入した雷電流は，初期には大 地に流出する割合が高いが, 徐々に連接接地線に流出する 割合が高くなっている。連接接地線への流出率は, タワー 脚部電流に対して， $5 \mu \mathrm{s}$ 時点で $15 \%, 30 \mu \mathrm{s}$ 時点で $65 \%$ と なっている。連接接地線への電流流出量は, 時間の経過と ともに上昇し, 最終的には各接地グリッドの接地抵抗の逆 比に等しい $80 \%(=2 \Omega / 2.5 \Omega \times 100 \%)$ が流出する。長岡 ら(7)の実測結果において, 雷撃を受けたタワー脚部の電流 の $80 \%$ 以上が連接接地線に流出しているのも, 上記と同じ 原因によるものと考えられる。

タワー中央の引き下げ線に流れる電流は示していないが, タワー脚部電流ピーク值の約 $4 \%$ のピーク值を有する電流 が流れている。

〈4・4〉 鉄筋コンクリート基礎とタワー脚部, 接地グリッ ド間の接続の影響＼cjkstart前節までは，鉄筋コンクリート基礎 とタワー脚部，接地グリッドとの間を電線で接続していな い場合を対象に計算を行ってきた。本節では，これらの間 が電気的に完全に接続されている場合の計算を行う。なお, 本節の計算では, 大地導電率は $10 \mathrm{mS} / \mathrm{m}$, 雷電流の立ち上 がり時間は約 $2.5 \mu \mathrm{s}$ とする。

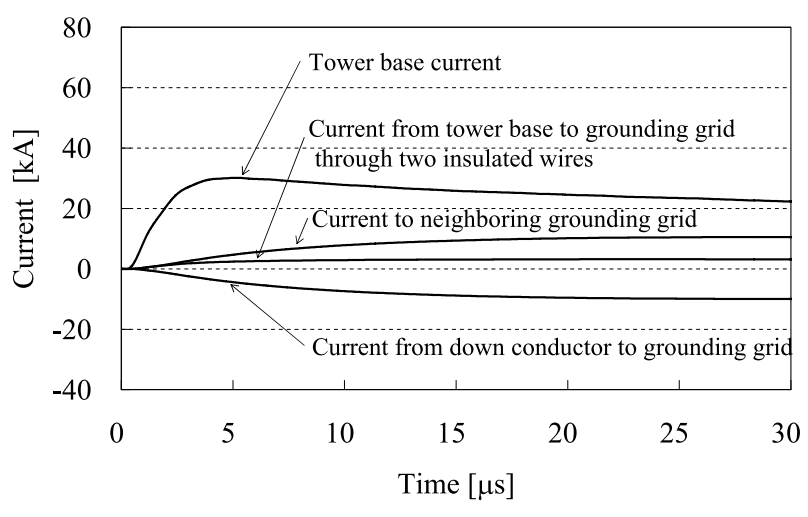

図 10 鉄筋コンクリート基礎とタワー脚部および 接地グリッドとの間を接続した場合における 雷撃を受けたタワー接地系各部の電流波形

Fig. 10. Waveforms of currents at different points within the grounding system for the lightning-struck tower when the steel-reinforced-concrete substructure is connected perfectly with the tower foot and to the grounding grid.

鉄筋コンクリート基礎と接地グリッド間は接続せずに, 鉄筋コンクリート基礎とタワー脚部を密着 (接続) させた場 合 (タワー脚部と接地グリッド, タワー内引き下げ線と接地 グリッドをつなぐ絶縁導体はそのまま）におけるタワー中 央の引き下げ線に流れる電流のピーク值は脚部電流ピーク 值の約 $2 \%$ となった。連接接地線への流出率は, 夕ワー脚部 電流に対して，5 $\mu \mathrm{s}$ 時点で約 15\%，30 $\mu \mathrm{s}$ 時点で約 50\%と なった。これらの比は, 鉄筋コンクリート基礎とタワー脚 部間に $0.5 \mathrm{~m}$ の導電率 $10 \mathrm{mS} / \mathrm{m}$ のギャップが存在する場合 の比（図 3 よび図 4 参照: $3 \% ， 20 \% ， 50 \%$ ）とそれほど変 わらない。

鉄筋コンクリート基礎とタワー脚部は接続せずに, 鉄筋コ ンクリート基礎と接地グリッドを 4 本の裸導体で接続した 場合における夕ワー中央の引き下げ線に流れる電流のピー ク值は脚部電流ピーク值の約 $2 \%$ となった。連接接地線へ の流出率は, タワー脚部電流に対して, $5 \mu \mathrm{s}$ 時点で約 $15 \%$, $30 \mu \mathrm{s}$ 時点で約 $50 \%$ となった。これらの比は, 鉄筋コンク リート基礎と接地グリッド間を接続していない場合の比と ほぼ同じである。

鉄筋コンクリート基礎とタワー脚部および接地グリッド の間を接続した場合におけるタワー脚部の電流波形，タワー 脚部から接地グリッドに流入する電流波形, タワー内引き 下げ線から接地グリッドに流入する電流波形および連接接 地線への流出電流波形を図 10 に示す。この場合には，鉄 筋コンクリート基礎を介して接地グリッドに流入する電流 が増えるため, タワー脚部と接地グリッドをつなぐ 2 本の 絶縁導体に流れる電流が図 3 のそれと比較して極めて小さ くなっている $(30 \mu \mathrm{s}$ 時点において, 図 3 では脚部電流の 約 50\%, 図 10 では脚部電流の約 10\%)。一方, 連接接地線 への流出率については, タワー脚部電流に対して， $5 \mu \mathrm{s}$ 時 点で約 $15 \%, 30 \mu \mathrm{s}$ 時点で約 $50 \%$ となった。この比は, 鉄 
筋コンクリート基礎と接地グリッド間を接続していない場 合の比と同じである。このことは, タワー脚部から接地グ リッドへの雷電流の主たる経路が内部絶縁導体から鉄筋コ ンクリート基礎に変わるのみで, 連接接地線への流出電流 はそれほど変化しないことを示している。タワー中央の引 き下げ線に流れる電流のピーク值は脚部電流ピーク值の約 2\%であり，これについても鉄筋コンクリート基礎と接地グ リッド間を接続していない場合の比とほぼ同じである。

\section{5. 結言}

本論文では，FDTD 法を用いて，雷撃を受けた風力発電 タワーの接地系各部の電流分布の計算を行った。その結果, 以下の事項が明らかになった。

雷電流の急峻成分については，雷撃を受けたタワーの接 地グリッドを介して大地に流出する割合が高い。急峻成分 の連接接地線への流出率は大地導電率が低いほど高くなる。

雷電流の緩やかな成分は各接地グリッドの接地抵抗值の 逆比で各接地グリッドに分流することが確認された。例え ば，雷撃タワー接地グリッドと隣接タワー接地グリッドがそ れぞれ $2 \Omega$ の接地抵抗を有する場合には, 雷撃タワーの脚部 電流の約 $50 \%$ が連接接地線に流出する。また, 雷撃夕ワー 接地グリッドの接地抵抗が $2 \Omega$, 隣接タワー接地グリッド のそれが $0.5 \Omega$ 場合には, 雷撃タワーの脚部電流の $80 \%$ 近 くが連接接地線に流出する。

今後は，本論文で得られた接地系各部の雷電流分布に関 する結果に基づき, 雷撃タワーおよび隣接タワー内部に生 じる電磁界および内部回路に生じる過渡電圧について検討 を進める予定である。

本研究は科学技術研究費補助金若手研究 B (18760220) の補助を受けて行われたことを記し，関係各位に感謝致し ます。

(平成 19 年 12 月 6 日受付, 平成 20 年 5 月 25 日再受付)

\section{文献}

(1) S. Enmei and M. Ideno: "Lightning damage realities of wind power generation systems", 2007 National Convention Record, IEE Japan, No.7-S8-2 (2007) (in Japanese)

延命正太郎・出野 勝:「風力発電設備の雷害実態」, 平成 19 年電気 学会全国大会, No.7-S8-2 (2007)

(2) K. Yamamoto, T. Noda, S. Yokoyama, and A. Ametani: "An experimental study of lightning overvoltages in wind turbine generation systems using a reduced-size model", IEEJ Trans, PE, Vol.126, No.1, pp.65-72 (2006-1) (in Japanese)

山本和男・野田 环・横山 茂・雨谷昭弘：「縮小モデルを用いた 風力発電システムの雷過電圧に関する実験的検討」, 電学論 $\mathrm{B}, \mathbf{1 2 6}, 1$, pp.65-72 (2006-1)

(3) K. Yamamoto, T. Ohta, T. Noda, S. Yokoyama, and A. Ametani: "An experimental study of lightning overvoltages in wind turbine generation systemsexperiments using a reduced-size model on actual soil", IEEJ Trans, PE, Vol.126, No.12, pp.1230-1238 (2006-12) (in Japanese) 山本和男 · 太田朋克 - 野田 环 - 横山 茂 $\cdot$ 雨谷昭弘：「風力発電シ ステムの雷過電圧に関する実験的検討一実際の土䁃における縮小モ デル実験」, 電学論 B, 126, 12, pp.1230-1238 (2006-12)

(4) Y. Yasuda, T. Hara, and T. Funabashi: "Analysis on lightning surge propagation in wind farm", IEEJ Trans, PE, Vol.125, No.7, pp.709-716 (2005-7) (in Japanese)
安田 陽・原 武久・舟橋俊久：「ウィンドファームの雷サージ伝 搬解析」, 電学論 B, 125, 7, pp.709-716 (2005-7)

(5) Y. Yasuda, T. Yoshioka, and T. Ueda: "FDTD transient impedance analysis of ring earth electrode for wind power generation", The Papers of Technical Meeting on HV, IEE Japan, No.HV-06-41, pp.25-30 (2006) (in Japanese) 安田陽・吉岡卓磨・植田俊明: 「FDTD 方による風車環状接地電 極の過渡インピーダンス解析」, 電気学会高電圧研資, No.HV-06-41, pp.25-30 (2006)

(6) K.S. Yee: "Numerical solution of initial boundary value problems involving Maxwell's equations in isotropic media", IEEE Trans. Antennas Propagat., Vol.14, No.3, pp.302-307 (1966)

(7) N. Nagaoka, Y. Baba, A. Ametani, H. Morita, T. Azuma, and T. Yamamoto: "A measurement of current distribution characteristics due to lightning to a wind-turbine tower", Proc. of 2007 Annual Conference of Power \& Energy Society, IEE Japan, No.456 (2007) (in Japanese)

長岡直人 · 馬場吉弘 - 雨谷昭弘 - 森田祐志 - 東 竜也 - 山本達也： 「風力発電タワー雷撃時の電流分布特性測定」, 平成 19 年電気学会 $\mathrm{B}$ 部門大会, No.456 (2007)

(8) S. Yokoyama and H. Taniguchi: "The third cause of outages on power distribution lines due to lightning_-backflow current from customer's facility into power distribution line", T. IEE Japan, Vol.117-B, No.10, pp.13321335 (1997-10) (in Japanese)

横山 茂·谷口弘光:「第 3 の配電線雷害原因一需要家設備から配電 線への雷電流の逆流現象」, 電学論 B, 117, 10, pp.1332-1335 (1997-10)

(9) Z.P. Liao, H.L. Wong, B.-P. Yang, and Y.-F. Yuan: "A transmitting boundary for transient wave analysis", Science Sinica, Series A, Vol.27, No.10, pp.1063-1076 (1984)

10) K. Tanabe, A. Asakawa, M. Sakae, M. Wada, and H. Sugimoto: "Verifying the computational method of transient performance with respect to grounding systems based on the FD-TD method", IEEJ Trans. PE, Vol.123, No.3, pp.358-367 (2003-3) (in Japanese)

田辺一夫 · 浅川 聡 ·坂江摩己 · 和田 勝 - 杉本仁志 :「FD-TD 法 に基づく電力設備接地系の過渡応答解析手法の検証」, 電学論 B, 123, 3, pp.358-367 (2003-3)

(11) Y. Baba, N. Nagaoka, and A. Ametani: "Modeling of thin wires in a lossy medium for FDTD simulations", IEEE Trans. EMC, Vol.47, No.1, pp.54-60 (2005-1)

(12) 高橋健彦: 接地・等電位ボンディング設計の実務知識, オーム社 (2003)

(13) T. Noda and S. Yokoyama: "Thin wire representation in finite difference time domain surge simulation", IEEE Trans. PWRD, Vol.17, No.3, pp.840847 (2002)

(14) B.N. Gorin and A.V. Shkilev: "Measurements of lightning currents at the Ostankino tower", Elektrich., No.4, pp.64-65 (1984)

長 尾 光 紘 (学生員) 1984 年 11 月生。 2007 年 3 月同志社

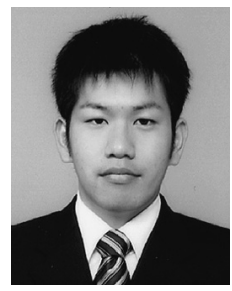
大学工学部電気工学科卒業。同年 4 月同大学大学 院工学研究科電気工学専攻博士課程 (前期) 入学, 現在に至る。FDTD 法を用いた電磁界解析に関す る研究に従事。

長 岡 直 人（正員） 1957 年 10 月生。1982 年 3 月同志社大

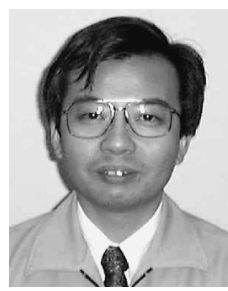
学大学院工学研究科博士前期課程修了。1985 年 同大学工学部助手, 1988 年同専任講師, 1992 年 同助教授。1999 年同教授，現在に至る。2005 年 10 月から 2006 年 9 月アイルランド国立大学ゴー ルウエイ校客員教授。2008 年 4 月から同志社大 学生命医科学研究科教授兼任。同志社大学入試セ ンター所長，アドミッションズオフィス所長。博 士 (工学)。電気回路シミュレーションおよび数值解析モデルの開発に 従事。1993 年電気設備学会論文賞, 1994 年照明学会論文賞受賞。電 気設備学会, 照明学会, IEEE，IET 会員。 
馬 場 吉 弘 (正員) 1971 年 2 月生。1 994 年 3 月東京大学工 学部電気工学科卒業。1 999 年 3 月同大学大学院工 学系研究科電気工学専攻博士課程修了。博士 (工 学)。同年 4 月同志社大学助手, 2001 年 4 月同専 任講師, 2005 年 4 月同助教授。 2007 年 4 月同准 教授，現在に至る。2003 年 4 月〜2004 年 8 月フ ロリダ大学客員研究員。電磁界パルスに関する研 究に従事。1999 年電気学会論文賞受賞。2007 年 AGU 雑誌ハイライト論文。AGU，IEEE，IET 会員。
雨 谷 昭 弘 （正員） 1944 年 2 月生。1968 年 3 月同志社大 学大学院電気工学専攻修士課程修了。1973 年又 ンチェスタ大学院博士課程修了。Ph.D. 1977 年同 志社大学助教授。1976 年から 1981 年米国 BPA にて EMTP の開発に従事。1985 年同志社大学教 授，現在に至る。1988 年 Leuven 大学教授兼任。 1966 年から 1998 年同志社大学理工学研究所所長。 1998 年から 2001 年同大学学術情報センター所長。 2005 年から 2008 年学校法人同志社評議員。2007 年から同志社大学 インフラストラクチャー研究センター長。分布定数回路, 過渡現象, 高調波, 数值解析法の開発に従事。英国技術士。2003 年電気学会理 事, 2004 年同副会長。1 1976 年電気学会論文賞, 1996 年照明学会論文 賞, 2006 年電気学会業績賞受賞。日本工学アカデミー会員。CIGRE 特別会員。IEEE，IET フェロー。 